\title{
Børnebibelen som kulturelt erindringssted mellem kirkekristendom og kulturkristendom
}

Av Kasper Bro Larsen

Børnebibelen som genre har $i$ de seneste årtier oplevet en bemarkelsesvardig opblomstring og popularitet. Denne artikel undersøger en rakke populare børnebibler på det danske marked som udtryk for kristen og samfundsmassig erindringsmobilisering (fx de Vries 1960, Møllehave 1996, Lindhardt 1998, Barrett 2010 og Jessen 2016). Hvor den autoriserede bibel udgør et delvist glemt arkiv, afspejler børnebiblerne den kulturelt erindrede bibelkanon. Artiklen undersøger, hvordan børnebiblerne konstruerer det bibelske i kraft af mekanismer som selvnormativisering, synkroni og syntopi, vardibaseret selektion, intratekstuelle forbindelser, tekstharmonisering og kulturel tilpasning. De danske børnebibler fastholder det bibelske i den kulturelle erindring ved at favne både kirkekristendom og kulturkristendom.

Nøgleord: børnebibler - kulturel erindring - Aleida Assmann - kulturel transmission - erindringssteder - evangelieharmonier - kirkekristendom kulturkristendom

Kasper Bro Larsen, f. 1972, Lektor ved Aarhus Universitet, Jens Chr. Skous Vej 3, 800 o Aarhus C, Danmark. E-post:kbl@cas.au.dk

\section{INDLEDNING - BØRNEBIBLER SOM BEST - OG STEADYSELLERE}

Børnebibelen som genre indtager en helt central rolle i kristendomsformidlingen i de skandinaviske lande i dag. Det ses ikke mindst af de imponerende salgstal, som børnebiblerne bliver ved med at præstere på bogmarkederne. Fra omkring 1960 og i de følgende tre årtier var markedet for børnebibler i Skandinavien domineret af hollandske Anne de Vries' børnebibel Groot Vertelboek voor de Bijbelse Geschiedenis fra 1939, der udkom i oversættelse på utallige sprog, herunder norsk, dansk og svensk i årene 1959-61 (de Vries 1939; de Vries 1959; de Vries 1960; de Vries 1961). Som den første børnebibel på børnelitterære præmisser var de Vries' bog en nyskabelse (Aller 2009: 297-298). I mange år havde den status af

1 Forfatteren ønsker at takke deltagerne ved seminaret Den skandinaviske Barnebibelen, Teologisk Fakultet, Universitet i Oslo, d. 7. juni 2018 for værdifulde kommentarer og diskussion. En særlig tak til arrangørerne Louise Heldgaard Bylund og Marianne Bjelland Kartzow. 
steadyseller; og alene i Danmark, hvor en bestseller normalt defineres som et værk med 10.000 solgte eksemplarer, er de Vries' nyklassiker solgt i mere end 146.000 eksemplarer (Knudsen 2010: 8).

Men meget er sket i kølvandet på De Vries' børnebibel. Det er ikke længere den, der dominerer; i stedet er markedet præget af mangfoldighed og konkurrence. Børnebibelen som genre har i de sidste omkring 25 år oplevet en bemærkelsesværdig og kreativ opblomstring. Dette er ikke mindst tilfældet i Danmark, hvor det er almindelig praksis, at Folkekirken forærer en børnebibel til dåbsfamilien i forbindelse med barnedåb. Det bliver til et betragteligt antal bøger, eftersom langt hovedparten af Folkekirkens for tiden over 40.000 årlige dåbshandlinger er barnedåb. Skønt de Vries' børnebibel fortsat udgives, er det ikke længere den, der oftest ligger ved døbefontene. I stedet møder vi Johannes Møllehaves Børnebibelen (1996; 260.000 solgt pr. 2010; 300.000 pr. 2017), Tine Lindhardts Sesams børnebibel (1998; salgstal uoplyst); Synne Garffs De mindstes bibel (2007; 45.000 solgt pr. 2010, over 100.000 pr. 2019); Sigurd Barretts Sigurd fortceller bibelhistorier (2010; 40.000 solgt efter blot et år; 160.000 pr. 2017) og Ida Jessens Bibelhistorier (2016; over 5.000 solgt pr. 2019). Flere af disse er desuden solgt til oversættelse i de skandinaviske lande. Hertil kommer udenlandske børnebibler oversat til dansk som amerikanske Bob Hartmanns Historiefortællerens børnebibel (1998; 20.000 solgt pr. 2010) og sydafrikanske Desmond Tutus Guds børn - bibelhistorier (2010; 6.000 solgt pr. 2019). ${ }^{2}$

At børnebibler på denne måde boomer - og jeg har ovenfor kun nævnt de børnebibler, jeg anslår til at være de mest populære - er næppe udtryk for nogen kristen vækkelse. Folkekirkens dåbstal er dalende, og danskerne gudstro er mere spirituel og ateistisk end bibelsk. ${ }^{3}$ Børnebiblernes udbredelse er snarere et udtryk for det forhold, som særligt cultural memory studies siden 1980'erne har gjort opmærksom på, at moderne samfund, skønt de ofte på webersk vis beskrives i kontrast til traditionelle samfund, på ingen måde er traditionsløse. I dagens Danmark synes børnebiblerne derimod at participere i en mere generel tendens i retning af øget fokus på identifikation, konservering og transmission af såkaldt kulturbærende værdier. Disse anses for at udgøre sammenhængskraften i det danske samfund og regnes for truet i en mere og mere pluralistisk

2 Forlagene er notorisk tilbageholdende med at offentliggøre salgstal. De ovenstående cirkatal stammer dels fra omtaler i dagspressen (Nygaard 2005; Knudsen 2010; Pedersen 2011; "Sigurds børnebibel" 2011; Johansson 2017; og Øhrstrøm 2017) dels fra direkte email-korrespondance med forlagene. Dagbladenes bestsellerlister rummer i øvrigt sjældent præcise tal, men giver et øjebliksbillede af aktuelle bøgers relative popularitet på markedet. I Berlingske Tidende d. 28. maj 2010 kunne man således notere sig, at hele to danske børnebibler (Møllehave 1996 og Barrett 2010) lå på ugens top 10-liste i kategorien børne- og ungdomsbøger. Barretts børnebibel lå i flere uger som nummer 1 på listen (Schelde 2010).

3 Ifølge en ny undersøgelse er danskernes gudsbillede for omkring halvdelens vedkommende spiritualistisk (48\%), mens en lille tredjedel er ateister (29\%) og kun 17\% tror på Gud "som beskrevet i Bibelen" (Pew Research Center 2018, 106-109). I denne del af undersøgelsen deltog kun ikke-muslimer; usikre og flertydige besvarelser blev ikke medtaget i undersøgelsens resultater. 
og globaliseret tidsalder. ${ }^{4}$ Denne generelle erindringsmobilisering har givet sig udslag i flere kanonprojekter initieret af (borgerlige) regeringer. Det gælder fx Kulturkanonen over de vigtigste danske værker udvalgt af fageksperter inden for kunstarter som arkitektur, film og litteratur (Kulturministeriet 2006), og den mere demokratisk udvalgte Danmarkskanon (2016) over "de samfundsværdier, traditioner og bevægelser, vi er formet af og fælles om, og som er værd at tage med ind i fremtidens samfund" (Kulturministeriet 2016).

Denne artikel har til formål at undersøge de mest populære danske børnebiblers funktion som kulturelle erindringssteder (lieux de mémoire, Nora 1984-1992), dvs. som materielle manifestationer af fælles forestillinger om den bibelske fortid og dens nutidige betydning. Som vi skal se, gør børnebiblerne som sådan brug af en række velkendte erindringsteknikker, der tilsammen er med til at gøre børnebiblerne til en manifestation af den kulturelt erindrede bibel, en bibel, der favner både dansk kirkekristendom og kulturkristendom. ${ }^{5}$

\section{B $\emptyset$ RNEBIBELEN SOM ERINDRINGSSTED}

Hvor historievidenskaben traditionelt interesserer sig for fortiden som fortid, fokuserer cultural memory studies på, hvordan samfund bruger fortiden som nutid i den fælles identitetsdannelse. ${ }^{6}$ Ifølge Aleida Assmann sker dette i form af kollektive erindrings- og glemselsprocesser, der kan være både aktive og passive. For at noget kan erindres, må andet glemmes. Aktiv glemsel finder sted, når samfundsaktører bevidst arbejder på at $\emptyset$ delægge, censurere eller tabuisere eksisterende kulturgods. Passiv glemsel er den ubevidste misligholdelse eller tilsidesættelse af samme. Tilsvarende kan også erindringen være både aktiv og passiv. Den passive erindring, sådan som den akkumuleres i arkiver, er en kulturs lagringshukommelse ("reference memory"), mens den aktive erindring, som selekteres til at stå fremme på udstillinger og i det offentlige rum, er kulturens arbejdshukommelse ("working memory"; Assmann 2008: 274; Assmann 2010: 99).7 Assmann betegner et samfunds lagringshukommelse som dets "arkiv", mens arbejdshukommelsen kaldes "kanon". Mens arkivet kan tage enorm

4 Præst og tidligere lektor ved Teologisk Pædagogisk Center Povl Götke forklarede i et interview børnebiblernes popularitet på følgende måde: "Det vidner om, at den kristne grundfortælling stadig er vores grundfortælling, og at intet kan erstatte den. Folk synes, det er vigtigt at give fortællingerne videre. [...] Vi bliver mere opmærksomme på, at tingene ikke giver sig selv, og at vi nu skal kæmpe for vores grundværdier og inspirationskilder - og dermed børnebibelen" (Schelde 2010).

5 Børnebibler er et komplekst fænomen, der inviterer til multidimensionelle undersøgelser. Ved at fokusere på deres funktion som erindringssteder underprioriterer jeg andre dimensioner som fx bibelreception, børnebibelgenrens historie og forhold til aktuel børnelitteratur, dens implicitte pædagogik og dens forskelligartede ideologiske og teologiske indhold.

6 For antologier med forskningshistorie og vigtige bidrag fra forskellige grene af cultural memory studies (herunder fra kanoniske navne som Maurice Halbwachs, Pierre Nora samt Aleida og Jan Assmann) se Errl \& Nünning 2010 og Olick et al. 2011.

7 Fx er det næppe helt fortegnet at hævde, at hvor de 400 års dansk-norsk rigsfællesskab hører til den kanoniske arbejdshukommelse i norsk erindringskultur i kraft af $\mathrm{fx}$ 17. maj-fejring, ligger samme historiske periode i dansk selvforståelse af forskellige grunde på grænsen til glemsel som arkivalier i lagringshukommelsen. 
størrelse - og rent faktisk gør det i vor tid med de nærmest uendelige muligheder for digital lagring - består den kanoniske arbejdshukommelse af et begrænset antal normative og formative erindringssteder i form af tekster, geografiske lokaliteter, monumenter, personer, signifikante genstande, begivenheder og myter, der aktivt markeres, cirkuleres og kommunikeres i stadigt nye udgaver og manifestationer. Kendetegnende for de kanoniske erindringssteder er, (1) at samfundet definerer dem som relativt stabile og fikserede, hvorved de beskyttes mod tidens tand, (2) at de består af et bestemt udvalg af fortidige fænomener, der er udvalgt gennem magtkampe, (3) at de tillægges en ukrænkelig værdi og hellig aura, og (4) at de kommunikeres på tværs af generationer med henblik på overlevering - til forskel fra kun private hitlister (frit efter Assmann 2008: 276-277). Som vi skal se, er dette også tilfældet for børnebiblerne som erindringssted.

Bibelen er en antik jødisk og kristen tekstsamling, som fortsat har kanonisk status i Assmanns forstand, al den stund dens fortællinger eksempelvis optræder som et af kristendomskundskabsfagets fire grundlæggende kompetenceområder i den danske folkeskole. ${ }^{8}$ Bibelen er som sådan fikseret som kanonisk erindringssted og som idé, skønt den kan manifestere sig i utallige former (autoriseret oversættelse, nudansk oversættelse, tekstkritisk udgave, genfortælling, børnebibler etc.), således at ingen konkret manifestation kan udpeges som dens egentlige udtryk - hvilket jo også gælder så mange andre kanoniske erindringssteder som fx den lille havfrue i Danmark og birkebeinerne i Norge. ${ }^{9}$ Går vi til Bibelens konkrete indhold, er det dog kun bibeleksegeter som mig selv, der bilder sig ind, at Bibelen hører til kulturens kanoniske arbejdshukommelse. Snarere må vi sige, at den autoriserede oversættelse af Bibelen mestendels er passivt glemt og derfor udgør en lagringshukommelse eller et arkiv i Assmanns forstand, et bagkatalog, hvorfra kulturen og kirken udvælger bestemte fortællinger, udsagn, begivenheder og personer til den kanoniske arbejdshukommelse - som udgør den kulturelt erindrede bibel.

\section{BøRNEBIBELEN SOM KULTUREL TRANSMISSION}

Børnebiblerne er et særligt prægnant udtryk for den kulturelt erindrede bibel. For mange børn foranstalter de det første møde med det bibelske. Flere børnebibler gør i deres forord opmærksom på bogens unikke betydning og aura som normativ og formativ for nutiden og fremtiden. Den danske udgave af Anne de Vries' børnebibel har, siden den først udkom, til forskel fra den norske udgave

8 Den officielle læseplanen for kristendomskundskabet lyder: "Det bibelske univers har i markant grad præget såvel tænkning som moral og livsforståelse i vestlig og dermed også dansk kultur, hvorfor denne ikke forstås uden et grundigt kendskab til en række af de bibelske fortællinger" (Undervisningsministeriet 2018: 10).

9 Frem for at tale om Bibelen i bestemt form foretrækker Timothy Beal således at tale om forskellige diskursive konstruktioner af "det bibelske": "[W]e are compelled to consider children's Bibles as Bible in and of themselves. They are creations of the biblical in specific cultural contexts" (Beal 2012: 313; jf. Beal 2011). 
været forsynet med forskellige forord. I 1960 var det Københavns biskop Hans Fuglsang-Damgaard, der anbefalede bogen som formidling af "Guds-ordet - vor største rigdom", som "ikke kan erstattes af noget som helst" (de Vries 1960: 5). Sigurd Barrett skriver i sit forord, at bibelhistorierne er "helt uundværlige" og "verdens vigtigste tekst" (Barrett 2010: 3-4). I kraft af sådanne paratekster, der omgiver den egentlige bibelfortælling, understreger udgiverne, at det bibelske står og skal stå i centrum af den kulturelle bevidsthed. ${ }^{10}$ Børnebiblerne har til formål at overføre samfundets mest centrale tekster til næste generation. Som en af børnebiblerne formulerer det $\mathrm{i}$ form af en dedikation: "Til Tyler og den nye generation" (Lindhardt: 1; jf. de Vries 1960: 5; 1983b: 5). Børnebiblerne er som erindringssteder en form for eksogrammer, for at bruge Merlin Donalds udtryk (Donald 2001: 309), dvs. materielle, symbolske lagringsenheder, der ikke er bundet til den individuelle krop eller hjerne, men som eksternt opbevarer og relativt fastfryser den fælles erindring - en form for kulturelle USB-stik - der muliggør kulturel transmission uden om de individuelle kroppes hukommelseskapacitet og formidlingskompetence.

For at få betydning hos nye individuelle kroppe skal børnebiblerne som eksogrammer naturligvis afkodes i forbindelse med selvlæsning eller højtlæsning og dermed internaliseres i nye individuelle kroppe og hjerner. Som Aleida Assmann skriver: "What has been externalized can only be maintaned in the circulation of cultural memory if it is reactivated, actualized, reincorporated, internalized" (Assmann 2008: 286). Børnebiblernes forord kan således tale om, at ordene skal "finde vej ind i barnesind" (de Vries 1960: 5) og bane "vejen til børns hjerter" (jf. Barrett 2010: 4). Der kan også være tale om direkte appeller til barnet: "Hvis du tager historierne fra denne bog med dig i hjertet, så er du godt på vej til at få en masse godt ud af det liv, du har fået. Og selvfølgelig vil du huske, hvor vigtigt det er at være god over for andre mennesker, dyr og væsener" (Barrett 2010: 274-275). Til at underst $\emptyset$ tte denne internalisering lægger en del børnebibler op til, at barnets eget navn indskrives med håndskrift først i bogen for at styrke barnets identifikation med bogen, så den bliver et personligt minde: "Til [...] Fra [...] Dato [...]" (Møllehave 1996: første opslag), "Til [...] Fra [...] Dato [...]" (Garff 2007: 1), "Denne bog blev givet til [...] i anledning af [...]" (de Vries 2008: 5) og "Denne bog tilhører [...]" (Barrett 2010: første opslag). På bagsiden af Møllehaves børnebibel står tilmed et digt, der lader barnet, der har fået bogen, selv udtrykke sit forhold til den: "Jeg ved, hvad denne bibel / blev købt til, / for her kan jeg høre / om det, jeg blev døbt til." (Møllehave 1996: bagsiden). Det er en form for ideel læser, der taler. Jeg'et i digtet har internaliseret det bibelske

10 For yderlige om paratekstualitet se Genette 1997a og 1997b. Hos Genette er paratekster betegnelse for de tekster, der omgiver et værk som fx en romans titel, forside og bagsidetekst med forfatterpræsentation, kort uddrag, illustration og citat fra anmeldelse. Parateksterne former læserens forforståelse af teksten. 
eksogram i en sådan grad, at det selv kan udtrykke det bibelskes identitetsdannende betydning. ${ }^{11}$

\section{FORTIDEN SOM NUTID - SYNKRONI OG SYNTOPI}

Som udtryk for den kulturelt erindrede bibel er børnebiblerne meget lidt interesserede i den bibelske fortid som fortid, men i fortiden som nutid. Dette gælder i særlig grad de børnebibler, der ud over rent narrativt at genfortælle også eksplicit kobler de bibelske fortællinger til barnets nutidsvirkelighed. If $ø$ lge Aleida Assmann er den kulturelle erindrings formål netop at knytte nutiden til en fælles fortid ved hjælp af det, hun kalder "diachronic communication" (Assmann 2008: 273). Hos Anne de Vries findes sådanne eksplicitte koblinger fx i 1960-udgavens illustrationer. Generelt er illustrationerne historiserende, orientalistiske og fortidsrettede, men ved bogens begyndelse og afslutning indrammes bibelfortællingen af nutidsillustrationer (de Vries 1960: 3, 253, 255). På titelbladet ses nutidsbørn således samlet omkring en bog - muligvis de Vries' egen børnebibel - mens bogens sidste sider kobler til læserens nutid ved at vise et billede af en højtlæsningssituation i et nutidigt børneværelse. Temaet på disse sidste sider i bogen er Jesu fortsatte nærvær og genkomst, hvorfor den allersidste illustration også får en tilsvarende sammenkoblende funktion. Jesus er fortidig og klædt i fortidig dragt, men den gruppe, som han modtager med åbne arme er en forsamling af nutidsfamilier klædt i nutidst $ø$ j. Skellet mellem fortid (Jesus) og nutid (familierne) er her ophævet i en synkroni (samme tid), men også i en syntopi (samme sted). Dette kommer ikke mindst til udtryk i den danske andenudgave, hvor scenen har fået tilføjet mere til sin baggrund. $\mathrm{Nu}$ ses der ikke bare et fortidigt Jerusalem bag Jesusskikkelsen, men også en nutidig storby med højhus og fjernsynstårn bag nutidsfamilierne. Fortidsbyen og nutidsbyen er forbundet af den samme paradisisk grønne eng med æbletræer (de Vries 1983b, 254-255). Børnebibelen har således ophævet afstanden mellem før og nu, mellem der og her. ${ }^{12}$

Synkroniske og syntopiske koblinger dyrkes i særlig høj grad i Sigurd fortceller bibelhistorier. Her er hvert kapitel indrammet af dels en indledning med spørgsmål og referencer, der relaterer til læserens nutidserfaring, fx "Hvor kommer vi alle sammen fra?" (Barrett 2010: 9) og "Hvorfor holder vi påske?" (ibid.: 243), dels af afsluttende sange, der kobler bibelfortællingen til nutiden ved at inddrage nutidsfænomener som computer, scooter og biler (ibid.:

11 For et interessant antropologisk studium af kristne praksisser (sanglege m.m.) til etablering af børns identifikation med Bibelen som hellig artefakt, se Malley 2004. Møllehave lægger i denne forbindelse vægt på den gentagne højtlæsningssituation: ”De voksne kan læse / for mig hver uge / om Noa, som åbnede / arkens luge, / om Rakel og Sara / og profeter og præster, / om jul og påske / og jødiske fester ..." (Møllehave 1996: bagsiden).

12 Se det tilsvarende skift fra historiserende illustrationer til nutidsillustrationer i den norske udgave (de Vries 1959: omslaget, 252-253) og den svenske (de Vries 1983a: omslaget, 253, 255). 
208-209). I selve genfortællingen bortfalder desuden fortidsord som "levit" og "statholder" og erstattes med nutidsord som "kirketjener" og "statsminister" (ibid.: 185, 189, 248). Og illustrationerne lader Jesus bære smart nutidig kasket (ibid.: 170, 173-174, etc.), ligesom præsten i lignelsen om den barmhjertige samaritaner fremstilles som nutidig dansk folkekirkepræst (ibid.: 184, 188). Tydeligt sammensmeltende synkronier og syntopier opstår i illustrationerne af Jesu fødsel, idet billedet med den fortidige Jesus i krybben er pyntet med nutidig gran og julehjerter som var det en traditionel dansk jul (ibid.: 156, se 158-159), mens billedet overfor af en nutidig dansk jul med juletræ og julehjerter viser den selvsamme julestjerne på træet, som de fortidige vise mænd så på himlen (ibid.: 153, 155), og som Jesusbarnet legede med i krybben (ibid.: 157). Uden for henholdsvis den fortidige stald og den nutidige stue lyser den samme stjernenat. Og som hos de Vries slutter Barrett sin børnebibel i nutiden. Det sidste kapitel ("Hvad sker der i kirken?") lader den bibelske historie pege frem mod Folkekirkens praksisverden med gudstjeneste, bibellæsning og overgangsritualer. Desuden lyder en appel: "Men historien fortsætter. Den fortsætter hos dig! Nu er det nemlig dig, der kan tage historierne til dig, og du kan også lave nye historier" (ibid.: 274). Den diakrone kommunikation rækker fra den normative fortid til nutiden og videre ind i fremtiden..$^{13}$

\section{BøRNEBIBLERNES SELEKTION - KANON I KANON}

En kulturs aktive erindring kan som nævnt kun være begrænset. Den bliver til, ikke ved naturlig, men ved kulturel selektion. Samfundets aktører kæmper indbyrdes om, hvilke elementer fra fortiden, der kan forsvinde i glemslens mørke og hvilke, der kan bruges i den fortsatte identitetsdannelse og evt. sanktioneres institutionelt. Fx har de fleste stater en officiel helligdagskalender, der markerer hvilken religiøs, national eller heroisk fortid, der i kraft af højtideligholdelse og ceremonielle genopførelser fortsat skal gælde som fælles nutid - samtidig med at denne også mange steder er til konstant forhandling (Connerton 1989). Og skolernes historiebøger fremhæver krige som Anden Slesvigske Krig (1864) og Anden Verdenskrig (1940-1945), men glemmer svimlende meget, hvorfor Charles Ingrao da også har kaldt skolebøger for "weapons of mass destruction" (citeret efter Assmann 2008: 279). Den autoriserede bibel er som bekendt i sig selv et udvalg af århundreders israelitiske, jødiske og kristne oldtidstekster, hvorfra børnebiblerne selekterer yderligere, så de etablerer en form for kanon i kanon.

Udvælgelseskriterierne bag børnebiblerne er sjældent eksplicit formuleret som var der tale om en selvforklarende, naturlig selektion fra en usynlig hånd.

13 I forhold til Sigurd fortcller bibelhistorier er illustrationerne i de øvrige børnebibler mere historiserende med enkeltvise undtagelser, som da Maria og Josef rider alene ud i mørket væk fra den ugæstfrie storby med nutidige hoteller og lysreklamer (Garff 2007: 158-159). 
Men udvælgelsen er naturligvis i høj grad præget af Bibelens virkningshistorie (Wirkungsgeschichte), dvs. den kirkelige og kulturelle receptionshistories etablerede vaner og traditioner om, hvad Bibelen betyder, og dermed også om, hvad der er centralt og perifært i det bibelske univers. ${ }^{14} \mathrm{Og}$ så er der en forkærlighed for Bibelens narrative tekster på bekostning af poesi ( $\mathrm{fx}$ Salmernes Bog) og brevlitteratur (fx Paulus' breve). Nogle børnebibler hævder at bestå af Bibelens bedste historier, men specificerer ikke yderligere: "60 af de allerbedste historier" (Lindhardt 1998: bagsiden), "50 af Bibelens allerbedste historier" (Garff 2007: bagsiden) og "Sigurd Barrett har udvalgt 24 af sine yndlingshistorier fra Bibelen" (Barrett 2010: bagsiden). ${ }^{15}$ Der er tekster, som praktisk taget altid er med, fx skabelsesberetningen og uddrivelsen fra Paradis (1 Mos 1-3), Kain og Abel (1 Mos 4,1-16), David og Goliat (1 Sam 17), Jesu fødsel (Matt 1-2; Luk 1-2), lignelsen om den barmhjertige samaritaner (Luk 10,25-37) og Jesu død og opstandelse (Mark 14-16 par.). Dernæst er der tekster, som nogle gange er med, andre gange ikke, fx David og Batseba (2 Sam 11,1-12,25), Jobs bog, Lazarus' opvækkelse (Joh 11,1-44) og Emmaus-vandringen (Luk 24,13-35). Endelig er der tekster, som aldrig kommer med, fx om den fulde vindyrker Noa (1 Mos 9,18-29), Saraj hos Farao (1 Mos 12,10-20), Lot og hans døtre (1 Mos 19,29-38), Prædikerens bog, Jesu forbandelse af figentræet (Mark 11,12-14.19-26 par.), Jesu apokalyptiske tale (Mark 13 par.), Ananias og Safira (ApG 5,1-11) og dommen over Babylon og Djævelen i ildsøen ( $\AA$ b 18-19). Ser man således på, hvad børnebiblerne ikke rummer, tegner der sig konturer af de implicitte kriterier, der styrer den faktiske udvælgelse: den gode fortælling, det moralsk rigtige, det teologisk korrekte og det pædagogisk passende.

I kraft af dette relativt faste repertoire af fortællinger sker der i børnebiblerne en stabilisering af den kulturelt erindrede bibelkanon. At den kulturelt erindrede bibel ikke er lig med den autoriserede bibel, ses også tydeligt af børnebiblernes tendens til at medtage fortælleelementer, der ikke kommer fra den autoriserede bibel selv, men fra den senere gen- og videredigtning i løbet af bibelens virkningshistorie: Adam og Eva spiser et æble (fx Barrett 22-33), Maria og Josef ridder på et æsel (fx Garff 2007: 159), Jesus fødes i en stald (fx de Vries 1960: 152), stjernen står over stalden (fx Garff 2007: 160), vismændene ved Jesu fødsel forstås som tre vise mænd (fx Jessen 2016: 176), vismændene har navne (fx Lindhardt 1998: 307), Jesus fristes i Getsemane have (fx ibid.: 433) etc. ${ }^{16}$ Ingen af disse fortælleelementer findes sort på hvidt i den autoriserede bibel,

14 Til Hans-Georg Gadamers udtryk Wirkungsgeschichte se Gadamer 1960: 284-290.

15 Barrett tilføjer nogle fravælgelseskriterier: "Ikke alle Bibelens historier er efter min mening lige velegnede for de små, hvis skuldre ikke behøver bære alle menneskehedens problemstillinger" (Barrett 2010: 4-5).

16 Forestillingen om "Getsemane have" er en sammenfletning af på den ene side Matthæus-, Markus- og Lukasevangeliets omtale af "et sted, der kaldes Getsemane" (Mark 14,32 par.) og på den anden side Johannesevangeliets omtale af en unavngiven "have" (Joh 18,1). 
men regnes ikke desto mindre i den kulturelle erindring som bibelske på lige fod med elementer fra den autoriserede bibel. Børnebibelens kanon er en samling af Bibelens mest kendte fortællinger og virkningshistoriens indgroede vaner.

\section{B $\emptyset$ RNEBIBLERNE SOM INTRATEKSTUELLE SYSTEMER}

At børnebiblerne udvælger bestemte tekster fra det bibelske arkiv, er en velkendt sag. Men hertil skal tilføjes, at børnebiblerne ikke bare selekterer, men også sammensætter de selekterede tekster i ordnet rækkefølge og i sammenhæng med andre tekster, så de danner et samlet, narrativt forl $\emptyset \mathrm{b}$ af tekstdele, der semantisk belyser hinanden. Ligesom i den autoriserede bibel er der tale om en samling af oprindeligt selvstændige tekster, der i kraft af deres nye placering ved siden af andre tekster făr ny betydning i lyset af de øvrige tekster i forløbet. Teksterne danner således et intratekstuelt system, hvor de enkelte tekstdele indgår $i$ et intratekstuelt forhold til hinanden og er hinandens intratekster. ${ }^{17}$ Andre intratekstuelle systemer kan fx være biblioteker, tekstrækker, liturgier, sang- og salmebøger, pensumlister, museer, aviser og artikelsamlinger. Også her bestemmes de enkelte tekstdeles betydning $\mathrm{i} h \mathrm{~h}_{\mathrm{j}}$ grad af deres placering i det intratekstuelle system. Intratekstuelle systemer er nemlig sammensat efter deres egen logik, som rammesætter de selvstændige tekstdele i et forløb af tekster. Fx skifter Kim Larsens sang "Om lidt" betydning alt efter, hvilken plads den indtager i henholdsvis musikalbummets, koncertens, højskolesangbogens eller begravelsesliturgiens intratekstuelle forløb. Velkendt er ligeledes den kristne bibels ordning af tekster fra højst forskellige kontekster og epoker $i$ et frelseshistorisk forl $\emptyset \mathrm{b}$ fra Det Gamle Testamente med hhv. den jødiske fortid (Mosebøgerne og de historiske bøger), nutid (visdomsbøgerne, herunder salmerne) og fremtid (profeterne) til Det Nye Testamente med tilsvarende den kristne fortid (evangelierne og Apostlenes Gerninger), nutid (brevene) og fremtid (Johannes' Åbenbaring). Børnebiblernes udvalg af bibeltekster optræder typisk i den autoriserede rækkefølge med tydelig markering af de to dele, hhv. Det Gamle og Det Nye Testamente. Nogle børnebibler diskuterer overgangen fra Det Gamle til Det Nye Testamente i det intratekstuelle forløb, således at Gud som hovedperson ændrer karakter i forløbet (fx Jessen 2016: 159). Jessen kan også skabe særlig effekt ved at bryde væk fra den autoriserede bibels intratekstuelle rækkefølge, så fx lignelsen om den fortabte søn (Luk 15,11-32) fortælles midt under Jesu ophold hos de to søstre Martha og Maria (Luk 10:38-42; ibid. 240-248), hvorved lignelsens søskendetematik fremhæves. Jessens børnebibel slutter desuden ikke som den autoriserede bibel med åbning mod Jesu genkomst (jf. fx de Vries 1960 og Barrett 2010), men med Paulus, der under sit fangenskab

17 Intratekstualitet (om tekstdelenes indbyrdes interne relationer) er ikke på samme måde som intertekstualitet (om tekstens eksterne relationer) et veletableret litteraturteoretisk begreb (Sharrock 2000: 4). 
i Rom (ApG 28,11-31) forfatter kærlighedens højsang fra 1 Kor 13 (Jessen 2016: 318).

Men ikke alle intratekster i børnebiblernes fortælleforl $ø \mathrm{~b}$ er genfortællinger af bibelske tekster. Først og fremmest indgår illustrationerne som vigtige intratekster, ikke mindst i højtlæsningssituationen for børn, der endnu ikke selv kan læse. Også et vers fra en Grundtvigsalme kan optræde som intratekst (Møllehave 1996: 162; jf. de Vries 1960: 177, 221, 224). Møllehave og Barrett afslutter hvert kapitel med en frit selvkomponeret intratekst i form af et digt eller en sang, der opsummerer og uddrager bibeltekstens nutidige betydning ( $\mathrm{fx}$ Møllehave 1996: 163-164; Barrett 2010: 20-21). Barrett indleder desuden hvert kapitel med en intratekst, der vækker barnets nysgerrighed med udgangspunkt i dets egen erfaringsverden. I 2008-udgaven af de Vries' børnebibel slutter hele bogen med trosbekendelse og fadervor, således at bibelfortællingerne sammenkobles med Folkekirkens rituelle kernetekster og evt. barnets kropslige erindring i form af aftenbønsritual med fadervor (de Vries 2008: 286-288). Børnebibler er patchwork-tekster, hvor bibelske og ikke-bibelske tekstdele er syet sammen i forskellige intratekstuelle mønstre, så de hver især danner en konstruktion af det bibelske koblet til nutiden.

\section{BøRNEBIBLERNE OG DEN KULTURELLE BIBELHARMONI}

I et samfunds erindring kondenseres fortiden til enkelte, ikoniske begivenheder. D-dagen d. 6. juni 1944 fejres af eftertiden som det afgørende vendepunkt $i$ kampen mod Nazityskland, skønt Anden Verdenskrig historisk set rummede en række andre lige så vigtige skæbnetimer, korsveje og afgørende slag. 1960'ernes og 1970'ernes spredte opg $ø$ r med traditionelle sociale omgangsformer og kønsroller eksisterer i dag i den kulturelle erindring under pars pro toto-betegnelsen 1968. Og 9/11 (d. 11. september 2001) beskrives som indvarslingen af en ny global tidsalder, skønt den postkoloniale, islamistiske terrorisme på det tidspunkt allerede havde stået på i årtier. En lignende kondensering af fortiden møder vi i børnebiblerne, og den finder ikke kun sted i form af selektion, men også i form af harmonisering, særligt når det gælder den autoriserede bibels fire forskellige evangeliefortællinger om Jesus. ${ }^{18}$ Dels springer børnebiblerne i det intratekstuelle forl $\emptyset \mathrm{b}$ frit mellem fortællinger fra de forskellige evangelier, således at en fortælling fra Johannesevangeliet efterfølges af en fra Lukasevangeliet og derpå atter af en fra Johannesevangeliet, dels flettes evangeliernes forskellige udgaver af den samme scene sammen til én harmoniseret genfortælling med elementer hentet fra forskellige evangelier. Det gælder fx i forbindelse med Jesu

18 Der findes dog undtagelser som Ulf Nilssons Mästaren och de fyra skrivarna, som imidlertid ikke er en traditionel, genfortællende børnebibel, men en videredigtende fortælling for en bredere aldersgruppe (Nilsson 1994; findes også på dansk og norsk). 
død på korset, hvor Jesu syv korsord, der stammer fra hhv. Markusevangeliet (ét korsord), Lukasevangeliet (tre korsord) og Johannesevangeliet (tre korsord), optræder uden hensyn til deres oprindelige ophav - hvilket i øvrigt er ganske almindeligt i kristen tradition (de Vries 1960: 221; Møllehave 1996: 249; Lindhardt 1998: 439-440). For en historisk orienteret bibelforsker er der tale om mangel på sensitivitet over for evangeliernes teologiske egenart, men det er omvendt vigtigt at være opmærksom på, at dén evangeliefortælling, som står stærkest i den kulturelle erindring, ikke er de enkelte evangelisters, men den kulturelle evangelieharmoni, som børnebiblerne så tydeligt er udtryk for: en kulturel diatessaron. ${ }^{19}$ En sådan forenkling af fortiden er forudsætning for, at fortællingen kan fastholdes i den fælles erindring som "a long-term cultural program" (Assmann 2008: 277). Biskop Fuglsang-Damgaard beskrev netop også kompleksitetsreduktionen som en fordel for den kulturelle transmission i det førnævnte forord til de Vries' børnebibel: "[D]ens styrke ligger i dens enkelhed" (de Vries 1960: 5).

\section{KonKLUSION: B $\emptyset$ RNEBibLERNE MELLEM KIRKEKRISTENDOM OG KULTURKRISTENDOM}

Bestemte bibeludgaver kan i et samfund blive så dominerende, at de tenderer mod at inkarnere samfundets forestillinger om det bibelske. I den tysktalende verden har Lutherbibelen haft en sådan status, ligesom det er tilfældet for The King James Version i en engelsktalende kontekst. Intet enkelt værk kan i en dansk sammenhæng hamle op med dette, men børnebiblerne som genre er måske det nærmeste, vi kommer, både i kraft af genrens de facto popularitet og dens funktion i den kulturelle transmission. De mest populære børnebibler har endda evnet at tilpasse sig folkekirkens symbiose af kirkekristendom (belonging and believing) og kulturkristendom (belonging without believing; jf. Iversen 1996). ${ }^{20}$ Et godt eksempel på børnebiblernes adaptive evne er de med tiden tilrettede forskellige forord til de Vries' børnebibel. De genfortolker bogen i stadig nye sammenhænge og kommer derfor til at fungere som en slags udskiftelige adaptere mellem bogen og kulturens skiftende strømninger. For biskop Fuglsang-Damgaard var det en selvfølge, at de Vries' børnebibel skulle fungere på tværs af samfundsinstitutioner i en kristen enhedskultur: "Måtte Gud så rigt velsigne bogen, både i skole, i kirke og i hjem" (de Vries 1960: 5). Men i den anden udgave fra 1983

19 Begrebet diatessaron ("gennem fire") henviser til kirkefaderen Tatians sammenskrivning af de fire evangelier (Matthæus-, Markus-, Lukas- og Johannesevangeliet) til én harmoniseret Jesusfortælling. Hans Diatessaron udkom i anden halvdel af 100-tallet e.Kr.

20 At kulturkristendommen står stærkt i Danmark ses bl.a. af den føromtalte Danmarkskanon, hvor den kristne kulturarv (og netop ikke den kristne tro) blev stemt ind på top ti-listen ved siden af fænomener som fx velfærdssamfundet, kønsligestilling, hygge og tillid (Kulturministeriet 2016). For diskussion og nuancering af begreberne kirkekristendom og kulturkristendom se Nielsen 2016. 
- formentlig formuleret i lyset af den folkeskolelov, der tog forkyndelsen ud af folkeskolen (1975) - er skolen ikke længere nævnt. Forordets $\emptyset$ nske - nu skrevet af bogens oversætter, Georg S. Geil - lyder her, "[...] at bogen endnu en tid må kunne fortælle stykker af den bibelske verden ind i en ny generation - og være med til at åbne Bogen for barnet" (de Vries 1983b, 5). Med skolen således ude af billedet fremstår de Vries' børnebibel som en mere kirkekristen bog. I forbindelse med trykningen af et nyt oplag i 1993 blev dette kirkekristne forord imidlertid redigeret, så det åbnede sig mod et mere bredt kulturkristent segment. Den sidste sætning i citatet ovenfor blev således omformuleret til følgende: "[...] - og være med til at åbne vor kulturs grundbog, bibelen, for kulturens fremtid, vore børn og børnebørn" (de Vries 1993, 5). ${ }^{21}$

Det er denne åbning mod både det kirkekristne og det kulturkristne, der kendetegner de mest populære børnebibler på det danske marked som helhed. I en vis forstand kan børnebiblerne ganske vist ikke skæres over en kam. Nogle er primært narrative med få applikationsappeller (fx Lindhardt 1998; Garff 2007), mens andre er eksplicit forkyndende ( $\mathrm{fx}$ de Vries 1960; Møllehave 1996; Barrett 2010). Nogle er primært historiserende i deres illustrationer (fx de Vries 1960; Møllehave 1996; Lindhardt 1998), mens andre gennemgående inddrager nutidselementer ( $f x$ Barrett 2010). Nogle er henvendt til mindre børn (fx Lindhardt 1998; Garff 2007), mens andre er til større børn (fx Jessen 2016). På tværs af disse forskelle foreligger der dog en fælles ambition om at skabe en kulturelt erindret bibel for både kirke- og kulturkristendom. Det viser sig på forskellig måde. De primært narrative børnebibler favner den brede kulturkristendom ved at være forkyndelsesmæssigt diskrete og dermed fremstå som ideologisk neutrale (Lindhardt 1998; Garff 2007; Jessen 2016). Møllehaves børnebibel er kirkekristen i sit indhold, men åbner sig mod kulturkristendommen alene i kraft af Møllehaves navn som liberal præst, forfatter og kulturpersonlighed. Barrett er til gengæld (ligesom flere af forordene til den danske udgave af de Vries) helt eksplicit i sin henvendelse til både det kirkekristne og det kulturkristne segment:

Uanset om man er troende eller ej, synes jeg, at bibelhistorierne er helt uundvorlige, når vi skal prcesentere vores børn for de vordier, vores kultur bygger på. I mødet med livets mange udfordringer synes jeg, at vores børn skal føle sig rustet til at vide lidt om, hvilke vœerdier den kristne tro bygger på, og hvilke fortcellinger vores kultur er rundet af (Barrett 2010: 3).

21 I forbindelse med 15. oplag i 1996 undergik Anne de Vries' børnebibel en revision og forkortelse. Her citerede forlaget Geils kulturkristne forord fra 1993 og gik et skridt længere i samme retning: ”Forkortelsen har fjernet en del moralske pointer m.m., som hørte til en bog som denne for nogle årtier siden. På den måde kommer den nye tekst til at svare bedre til idealet for en moderne børnebibel" (de Vries 1996: 6). I 2008 udkom den seneste udgave: "Teksten er nænsomt blevet strammet op, så den svarer til vor tids forventning til en god børnebibel" (de Vries 2008: bagsiden). 
Bibelhistorierne er "[...] for børn $i$ alle aldre, der får et billede af det kristne budskab og de vordier, som vores kultur er rundet af" (Barrett 2010: bagsiden)..22

Som vi har set, gælder de samme mekanismer for kulturel erindring i børnebiblernes sammenhæng som i andre sammenhænge. Børnebiblerne opbevarer ikke fortiden som fortid, men rekonstruerer dens tekster i lyset af nutiden (Halbwachs 1992: 119). De er med til at fastholde forestillingen om det bibelske som udtryk for en oph $ø$ jet, fast og genkendelig fortid, der er formativ og normativ for nutiden og fremtiden. B $\emptyset$ rnebiblerne forenkler og harmoniserer, mens de kobler sig på ikke-bibelske intratekster med henblik på kulturel transmission til næste generation. Samtidig sikrer børnebiblerne det bibelske en plasticitet, så det både kan favne kirkekristendom og kulturkristendom. Som erindringssteder er børnebiblerne laboratorier for både traditionsbearbejdelse og traditionsformidling. De forandrer for at bevare.

\section{LitTERATUR}

Aller, Edith. 2009. Børns bibelhistorier - sprogbrug, historie og funktion. Frederiksberg: Aros Underviser.

Assmann, Aleida. 2008. "The Religious Roots of Cultural Memory" i Norsk Teologisk Tidsskrift 109, side 270-292.

Assmann, Aleida. 2010. "Canon and Archive" i Cultural Memory Studies: An International and Interdisciplinary Handbook. Media and Cultural Memory 8. Red. af Astrid Erll \& Ansgar Nünning. Berlin: Walter de Gruyter, side 97-108.

Barrett, Sigurd. 2010. Sigurd fortæller bibelhistorier. København: Politikens Børnebøger / Danmarks Kirkelige Mediecenter.

Beal, Timothy. 2011. "Reception History and Beyond: Toward the Cultural History of Scriptures" i Biblical Interpretation 19, side 357-372.

Beal, Timothy. 2012. "Childrens' Bibles Hot and Cold" i Text, Image, \& Otherness in Children's Bibles: What is in the Picture? Red. af Caroline Vander Stichele \& Hugh S. Pyper. Society of Biblical Literature Semeia Studies 56. Atlanta: Society of Biblical Literature, side 313-319.

Bylund, Louise Heldgaard. 2019. "Udvandringen fra Egypten er som et 17. majoptog uden bunader og flag. Børnebiblers interaktion med den kulturelle kontekst" i Prismet 70 (2), side 109-124.

22 For en analyse af børnebiblernes formulering af kulturbærende værdier se Louise Heldgaard Bylunds bidrag til dette nummer af Prismet (Bylund 2019). Sigurd Barrett udtaler i øvrigt i forlængelse af ovenstående: ”Jeg tror på Gud, og det er en daglig glæde, men jeg blander mig ikke i, om andre vil tro eller ikke. Dog synes jeg, at det er vigtigt at kunne fortælle historierne, som vores kulturkreds under alle omstændigheder er rundet af” (Kassebeer 2017). Barretts syntese af kirke- og kulturkristendom understreges af det forhold, at hans børnebibel er udgivet i et samarbejde mellem Danmarks Kirkelige Mediecenter og det mere brede forlag Politiken Børnebøger. 
Connerton, Paul. 1989. How Societies Remember. Themes in the Social Sciences. Cambridge: Cambridge University Press.

de Vries, Anne. 1939. Groot Vertelboek voor de Bijbelse Geschiedenis. Kampen: J.H. Kok. de Vries, Anne. 1959. Barnas bibelbok. Oversat til norsk af Else Thowsen. Oslo: Ansgar, 1959.

de Vries, Anne. 1960. Børnenes bibelbog. Oversat til dansk af Georg S. Geil med forord af biskop, dr.theol. H. Fuglsang-Damgaard. Fredericia: Lohse, 1960.

de Vries, Anne. 1961. Barnens bibel - Bibeln berättad för barn. Oversat til svensk af Britt G. Hallqvist. Örebro: I.P.C.

de Vries, Anne. 1983a. Barnens bibel - Bibeln berättad för barn. Oversat til svensk af Ylva Eggehorn. Aneby: KM-förlaget.

de Vries, Anne. 1983b. Børnenes bibelbog. 2. udg. Oversat til dansk af Georg S. Geil med forord af samme. Fredericia: Lohse.

de Vries, Anne. 1993. Børnenes bibelbog. 2. udg., 13. oplag. Oversat til dansk af Georg S. Geil med nyt forord af samme. Fredericia: Lohse.

de Vries, Anne. 1996. Børnenes bibelbog. 3. udg. Oversat til dansk af Georg S. Geil. Forkortet af Kerstin og Helge Hoffmann. Fredericia: Lohse.

de Vries, Anne. 2008. Børnenes bibelbog. 4. udg. Oversat til dansk af Georg S. Geil. Revideret af Thomas B. Mikkelsen. Fredericia: Lohse.

Donald, Merlin. 2001. A Mind so Rare: The Evolution of Human Consciousness. New York: Norton.

Erll, Astrid \& Ansgar Nünning, red. 2010. Cultural Memory Studies: An International and Interdisciplinary Handbook. Media And Cultural Memory 8. Berlin: Walter de Gruyter, side 97-108.

Gadamer, Hans-Georg. 1960. Wahrheit und Methode. Grundzüge einer philosophischen Hermeneutik. Tübingen: J.C.B. Mohr (Paul Siebeck).

Garff, Synne. 2007. De mindstes bibel. København: Bibelselskabet.

Genette, Gérard. 1997a. Palimpsests: Literature in the Second Degree. Lincoln: University of Nebraska Press. Fransk originaludgave: 1982.

Genette, Gérard. 1997b. Paratexts: Thresholds of Interpretation. Literature, Culture, Theory 20. Cambridge: Cambridge University Press. Fransk originaludgave: 1987. Halbwachs, Maurice. 1992. "Religious Collective Memory" i On Collective Memory. Red. af Lewis A. Coser. The Heritage of Sociology. Chicago: University of Chicago Press, side 84-119.

Hartmann, Bob. 1998. Historiefortæellerens børnebibel. Frederiksberg: Unitas.

Iversen, Hans Raun. 1997. "Kulturkristne, kirkekristne og karismatiske kristne"

i Fønix 21, s. 51-72.

Jessen, Ida. 2016. Bibelhistorier. København: Bibelselskabet.

Johansson, Susanne. 2017. "Johannes og bestsellerne" i BT 21. mar, sektion 1, side 6. 
Kassebeer, Søren. 2017. "Jeg tror på Gud, og det er en daglig glæde" i Berlingske Tidende, 18. december, sektion 3, side 3.

Knudsen, Marianne Nygaard. 2010. "Børnebibler når ud til et bredt publikum" i Kristeligt Dagblad 3. sep, sektion 2, side 8.

Kristeligt-Dagblad. 2006. "Religion er et privat anliggende." 23. maj [online]. Tilgængelig: https://www.kristeligt-dagblad.dk/kirke-tro/religion-er-et-privatanliggende [9. marts 2019].

Kulturministeriet. 2006. "Kulturkanonen." Tilgængelig: https://kum.dk/uploads/tx_ templavoila/KUM_kulturkanonen_OK2.pdf [9. marts 2019].

Kulturministeriet. 2016. "Danmarkskanonen." Tilgængelig: https://www.danmarkskanon.dk [9. marts 2019].

Lindhardt, Tine. 1998. Sesams børnebibel. Tekstudvalg af Pat Alexander. København: Sesam.

Malley, Brian. 2004. How the Bible Works: An Anthropological Study of Evangelical Biblicism. Cognitive Science of Religion Series. Walnut Creek: Alta Mira.

Møllehave, Johannes. 1996. Børnebibelen. København: Bibelselskabet.

Nielsen, Marie Vejrup. 2016. "Kulturkristen - en deskriptiv eller normativ betegnelse i Danmark i dag" i Religion nr. 2 juni, s. 64-70.

Nilsson, Ulf. 1994. Mästaren och de fyra skrivarna - en berättelse om Jesu liv och död, Stockholm: Natur och kultur. Oversat til flere sprog, herunder dansk og norsk.

Nora, Pierre, red. 1998. Realms of Memory: Rethinking the French past. Chicago: University of Chicago Press.

Nora, Pierre, red. 1984-1992. Les lieux de mémoire. Paris: Gallimard.

Nygaard, Else Marie. 2005. "Den pastelfarvede børnebibel" i Kristeligt Dagblad 17. aug, Kirke og Tro, side 4.

Olick, Jeffrey K., Vered Vinitzky-Seroussi \& Daniel Levy, red. 2011. The Collective Memory Reader. Oxford: Oxford University Press.

Pedersen, Annelise. 2011. "Møllen maler millioner" i Ekstra Bladet 7. aug, Flash, side 10.

Pew Research Center. 2018. "Being Christian in Western Europe." Tilgængelig: http:// www.pewforum.org/wp-content/uploads/sites/7/2018/05/Being-Christian-inWestern-Europe-FOR-WEB1.pdf [9. marts 2019].

Schelde, Nanna. 2010. "Børnebibel topper hitliste" i Kristeligt Dagblad 4. maj [online]. Tilgængelig: https://www.kristeligt-dagblad.dk/kirke-tro/børnebibel-topperhitliste [9. marts 2019].

"Sigurds børnebibel solgt i 40.000 eks." 2011. Udfordringen 24. marts, sektion 1, side 5 .

Sharrock, Alison. 2000. "Intratextuality: Texts, Parts, and (W)holes in Theory" i Intratextuality: Greek and Roman Textual Relations. Red. af Alison Sharrock \& Helen Morales. Oxford: Oxford University Press, side 1-39. 
Tutu, Desmond. 2010. Guds børn - bibelhistorier. København: Alfa.

Undervisningsministeriet. 2018. "Læseplan for faget kristendomskundskab." Tilgængelig: https://www.emu.dk/sites/default/files/Læseplan\%20for\%20 faget\%2okristendomskundskab.pdf [9. marts 2019].

$\emptyset$ hrstrøm, Daniel. 2017. "Fra bjørnen Bjørn til bibelhistorier og Luther" i Kristeligt Dagblad 20. jan., side 10. Tilgængelig: https://www.kristeligt-dagblad.dk/ mennesker/fra-bjoernen-bjoern-til-bibelhistorier-og-luther [9. marts 2019]. 